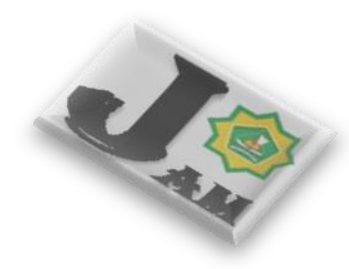

Al-Muqayyad

ISSN (print): 2715-3177 | ISSN (online): 2614-8102

Program Studi Ekonomi Syariah, STAI Auliaurrasyidin Tembilahan Journal Homepage: https://ejournal.stai-tbh.ac.id/index.php/al-muqayyad

\title{
Persepsi Nasabah terhadap Akad Rahn pada Pegadaian Syariah
}

*Sri Widiastuti ${ }^{1, \text { a }}$, Nurse Fatimah $\mathbf{M Z}^{2, \text { b }}$

1) UIN Sultan Syarif Kasim, Riau, Indonesia

${ }^{2)}$ STAI Auliaurrasyidin Tembilahan, Indragiri Hilir, Riau, Indonesia

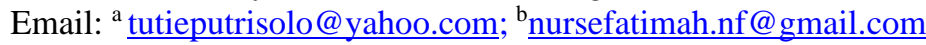

DOI:

https://doi.org/10.469

$\underline{\text { 63/jam.v4i1.376 }}$
Cara Mensitasi Artikel ini:

Widiastuti. S., \& Fatimah, M. Z. N. (2021). Persepsi nasabah terhadap akad rahn pada pegadaian syariah. AL-Muqayyad, 4(1), 70-83. https://doi.org/10.46963/jam.v4i1.376

\section{ABSTRACT}

Keywords:

Perception, Rahn, Pawnshop

\section{Kata Kunci:}

Persepsi, Rahn, Pegadaian

\begin{abstract}
This research was motivated by the author's preliminary observations regarding customers' points of view between Sharia Pawnshops, and conventional Pawnshops were the same, some customers thought that Sharia Pawnshops also apply interest, even though the system were different. The purposes of this study were to find out how the Rahn contract, and the customer's perception of the Rahn at the Syariah Pawnshops. Data analysis used qualitative descriptive by deductive, and inductive methods. The results showed that most of the customers did not understand the Rahn, but they believed that the pawn products available at the Sharia Pawnshop and the pawn products in conventional pawnshops were the same. Furthermore, the implementation of the Rahn contract at the Sharia Pawnshop was under Islamic roles because there were no rules that violate Islamic law.
\end{abstract}

\section{ABSTRAK}

Informasi Artikel:

Diterima:

19/05/2021

Direvisi:

$-$

Diterbitkan

$30 / 06 / 2021$

*Corresponding
$\begin{aligned} & \text { Author } \\ & \text { tutieputrisolo@yahoo }\end{aligned}$
.com

\section{PENDAHULUAN}

Dalam kegiatan sehari-hari, uang selalu saja dibutuhkan untuk membeli atau membayar berbagai keperluan. Yang menjadi masalah terkadang kebutuhan yang ingin dibeli atau membayar berbagai keperluan tidak dapat dicukupi dengan uang yang dimilikinya. Kalau sudah demikian maka mau tidak mau kita mengurangi untuk membeli berbagai keperluan yang dianggap tidak penting, namun untuk keperluan yang sangat penting terpaksa harus dipenuhi dengan berbagai cara seperti meminjam dari berbagai sumber dana yang ada. Jika kebutuhan dana dan jumlahnya besar, maka dalam jangka 
Persepsi Nasabah terhadap Akad Rahn pada Pegadaian Syariah

pendek sulit untuk dipenuhi, apalagi jika harus dipenuhi lewat lembaga perbankan. Namun jika dana yang dibutuhkan relatif kecil tidak jadi masalah, karena banyak tersedia sumber dana yang murah dan cepat, mulai dari meminjam ke tetangga sampai ke peminjaman dari berbagai lembaga keuangan lainya.

Bagi mereka yang memiliki barang-barang berharga kesulitan dana dapat segera dipenuhi dengan cara menjual barang berharga tersebut, sehingga sejumlah uang yang diinginkan dapat terpenuhi. Namun risikonya barang-barang yang telah dijual akan hilang dan sulit untuk kembali. Kemudian jumlah uang yang diperoleh terkadang lebih besar dari yang diinginkan sehingga dapat mengakibatkan pemborosan. Untuk mengatasi kesulitan yang ada di atas di mana kebutuhan dana dapat dipenuhi tanpa kehilangan barang-barang berharga, maka masyarakat dapat menjaminkan barang-barangnya ke lembaga tertentu. Barang yang dijaminkan tersebut pada waktu tertentu dapat ditebus kembali setelah masyarakat melunasi pinjamannya. Kegiatan menjaminkan barangbarang berharga untuk memperoleh sejumlah uang dan dapat ditebus kembali setelah jangka waktu tertentu kita sebut dengan nama usaha gadai. Dengan usaha gadai masyarakat tidak perlu takut kehilangan barang- barang berharganya dan sejumlah uang yang diinginkan dapat disesuaikan dengan harga barang yang dijaminkan.

Gadai (rahn) secara etimologi adalah ketetapan dan kelanggengan, secara terminologi gadai (rahn) adalah kepercayaan memberikan utang dengan jaminan berupa barang, di mana utang tersebut dapat dilunasi dengan barang tersebut atau utangnya separuh dari nilai barang, apabila utang yang menjadi tanggungan orang tersebut tidak dapat dilunasi. (Abdullah Bin Abdurrahman Al-Bassam: 2006)

Perkataan "pegadaian" di dalam Islam disebut juga dengan rahn, yang mana maksudnya adalah tanggungan, dalam pengertian yang lain Rahn berarti "kekal" atau "tetap" dan berdasarkan ahli Fiqih, ia dimaksudkan untuk pengertian pegadaian.

Akad rahn bertujuan agar pemberi pinjaman lebih mempercayai pihak yang berhutang, pemeliharaan dan penyimpanan barang gadaian pada hakikatnya adalah kewajiban pihak yang menggadaikan (rahin), namun dapat juga dilakukan oleh pihak yang menerima barang gadai (murtahin) dan biayanya harus ditanggung rahin. (M. Muslehuddin: 2004)

\section{Al-Muqayyad}

Vol. 4 No. 1 (2021) 
Adapun landasan Syariah Ar-Rahn disebutkan di dalam QS. Al-Baqarah (2): 283 sebagai berikut:

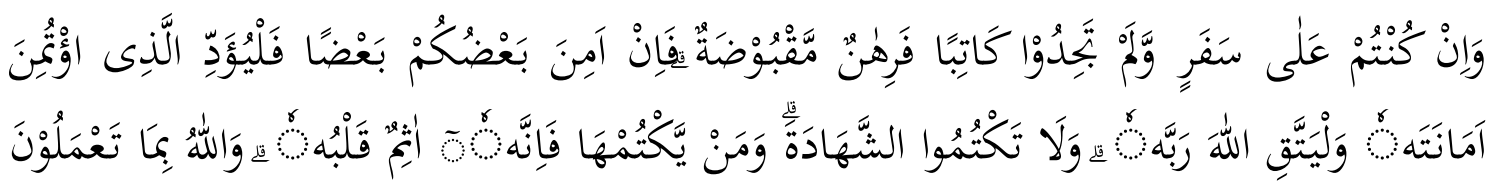

Artinya: jika kamu dalam perjalanan (dan bermu'amalah tidak secara tunai) sedang kamu tidak memperoleh seorang penulis, Maka hendaklah ada barang tanggungan yang dipegang[180] (oleh yang berpiutang). akan tetapi jika sebagian kaтu mempercayai sebagian yang lain, Maka hendaklah yang dipercayai itu menunaikan amanatnya (hutangnya) dan hendaklah ia bertakwa kepada Allah Tuhannya; dan janganlah kamu (para saksi) Menyembunyikan persaksian. dan Barang siapa yang menyembunyikannya, Maka Sesungguhnya ia adalah orang yang berdosa hatinya; dan Allah Maha mengetahui apa yang kamu kerjakan.

Ayat tersebut secara umum menyebutkan barang tanggungan yang dipegang (oleh yang berpiutang) dalam dunia finansial, barang tanggungan biasa dikenal sebagai jaminan (collateral) atau objek pegadaian. Dalam sebuah Hadits Rasulullah SAW bersabda:

Artinya: 'Aisyah r.a berkata bahwa Rasulullah membeli makanan dari seorang Yahudi dan menjaminkan kepadanya baju besi”. (H.R. Bukhari).

Sedangkan menurut Fatwa Dewan Syariah Nasional No.25/DSN-MUI/III/2002 bahwa pinjaman dengan menggadaikan barang sebagai jaminan hutang dalam bentuk rahn dengan ketentuan sebagai berikut:

1. Murtahin mempunyai hak untuk menahan marhun.

2. Marhun dan manfaatnya tetap menjadi milik rahin. Pada prinsipnya, marhun tidak boleh dimanfaatkan oleh murtahin kecuali seizin rahin.

3. Pemeliharaan dan penyimpanan marhun pada dasarnya menjadi kewajiban rahin, namun dapat dilakukan juga oleh murtahin, sedangkan biaya pemeliharaan penyimpanan tetap menjadi kewajiban rahin.

4. Besar biaya pemeliharaan dan penyimpanan marhun tidak boleh ditentukan berdasarkan jumlah pinjaman. (Rifqi Muhammad: 2008)

5. Penjualan marhun

a. Apabila jatuh tempo, murtahin harus memperingatkan rahin untuk segera melunasi hutangnya. 
Persepsi Nasabah terhadap Akad Rahn pada Pegadaian Syariah

b. Apabila rahin tetap tidak dapat melunasi hutangnya, maka marhun dijual paksa/dieksekusi melalui lelang sesuai syariah.

c. Hasil penjualan marhun digunakan untuk melunasi hutangnya, biaya pemeliharaan dan penyimpanan yang belum dibayar serta biaya penjualan.

d. Kelebihan hasil penjualan menjadi milik rahin dan kekuranganya menjadi kewajiban rahin.

Berdasarkan Fatwa Dewan Syariah Nasional No.26/DSN-MUI/III/2002 tentang Rahn Emas beberapa ketentuan yang diatur dalam fatwa ini, antara lain sebagai berikut:

1. Rahn Emas dibolehkan berdasarkan prinsip rahn.

2. Ongkos dan biaya penyimpanan barang (marhun) ditanggung oleh penggadai (rahin).

3. Ongkos sebagaimana dimaksud ayat 2 diatas besarnya didasarkan pada pengeluaran yang nyata-nyata diperlukan.

4. Biaya penyimpanan barang (marhun) dilakukan berdasarkan akad Ijarah. (Andri Soemitra:2010)

Pekanbaru sebagai sentral ekonomi juga telah disuguhkan dengan hadirnya berbagai produk jasa keuangan berbasis syariah, hal ini sebagai wahana bagi masyarakat muslim dalam mengaplikasikan kegiatan ekonomi yang syar'i sekaligus juga untuk memperkukuh eksistensi ekonomi Islam di tengah-tengah kehidupan masyarakat sebagai objek dari kegiatan ekonomi. Karena tidak dapat dipungkiri perkembangan masyarakat untuk lebih intens memanfaatkan ekonomi Islam semakin hari semakin meningkat, dan salah satu sektor ekonomi syariah yang tumbuh adalah Pegadaian Syariah, adanya fluktuasi ekonomi masyarakat muslim tentunya memberikan peluang bagi pegadaian syariah untuk mendapatkan tempat dihati kaum muslimin pada khususnya dan warga Pekanbaru pada umumnya, salah satu pegadaian syariah yang sedang eksis adalah Pegadaian Syariah cabang HR. Soebrantas yang memiliki lokasi strategis dan berada di kawasan Panam Pekanbaru. Pegadaian Syariah cabang HR. Soebrantas pertama berlokasi di Pandau Permai pada tanggal 20 November 2008, kemudian pada tanggal 02 Januari 2011 dipindahkan ke Jalan HR. Soebrantas KM 10,5 Panam yang merupakan unit dari Perum Pegadaian Persero cabang Pekanbaru.

Pada prinsipnya pegadaian syariah memiliki konsep pelaksanaan yang berbeda dengan pegadaian konvensional secara umum. Namun berdasarkan observasi penulis

\section{Al-Muqayyad}

Vol. 4 No. 1 (2021) 
terhadap nasabah pegadaian syariah, sering kali sistem yang diterapkan oleh pegadaian syariah tidak dipahami secara utuh oleh para nasabah sehingga tanggapan yang muncul di kalangan para nasabah adalah tidak adanya perbedaan antara operasional pegadaian syariah dan operasional pegadaian konvensional. Dalam sebuah wawancara yang penulis lakukan dengan seorang nasabah Pegadaian Syariah cabang HR. Soebrantas beliau menyampaikan "Pegadaian Syariah dan Pegadaian Konvensional itu sama saja", kemudian ada juga yang mengatakan bahwa "tidak ada bedanya antara pegadaian syariah dan pegadaian konvensional, sama-sama menerapkan bunga" Maka untuk mengetahui secara utuh persepsi nasabah terhadap Pegadaian Syariah sesuai dengan latar belakang di atas, penulis tertarik untuk melaksanakan penelitian lebih lanjut.

\section{METODE}

Penelitian ini termasuk jenis penelitian lapangan (field research) dengan pendekatan deskriptif kualitatif, karena yang menjadi sorotan adalah Pegadaian Syariah cabang HR. Soebrantas Pekanbaru sebagai pengelola. Perilaku, pola pikir, preferensi dan praktik pegadaian syariah dapat dipahami lebih baik. Alasan lainnya menggunakan pendekatan kualitatif adalah pilihan diri pribadi peneliti. Pilihan pribadi peneliti adalah legitimasi dan alasan yang tepat untuk menentukan suatu pilihan (Lincoln dan Guba, 1997).

Metode penelitian merupakan usaha penyelidikan yang sistematis dan terorganisasi. Artinya sistematis dan terorganisasi menunjukkan bahwa untuk mencapai tujuan, maka penelitian dilakukan dengan menggunakan cara-cara (prosedur) tertentu yang telah diatur dalam suatu metode yang baku. Metode penelitian berisikan pengetahuan yang mengkaji ketentuan metode-metode yang dipergunakan dalam langkah-langkah suatu proses penelitian. (Rosady Ruslan: 2010). Sedangkan penelitian riset (research) adalah suatu upaya secara sistematis untuk memberikan jawaban permasalahan atau fenomena yang kita hadapi (Punaji Setyosari: 2010).

Adapun tempat penelitian ini dilakukan di Pegadaian Syariah cabang HR. Soebrantas Pekanbaru, dengan menggunakan data yang diambil dari nasabah sebagai sumber utama pada kurun waktu tahun 2013.

Subjek dalam penelitian ini adalah karyawan dan nasabah produk rahn pada Pegadaian Syariah cabang HR. Soebrantas Pekanbaru. Sedangkan yang menjadi objek 
Persepsi Nasabah terhadap Akad Rahn pada Pegadaian Syariah

penelitian ini adalah persepsi nasabah terhadap aplikasi akad rahn pada Pegadaian Syariah cabang HR. Soebrantas ditinjau menurut perspektif ekonomi Islam.

Populasi dalam penelitian ini adalah karyawan Pegadaian Syariah cabang HR. Soebrantas dengan jumlah 3 orang dan nasabah produk rahn dengan jumlah 252 orang. dari jumlah populasi nasabah maka penulis mengambil $20 \%$ yaitu sebanyak 50 orang sebagai sampel, sampel ditentukan dengan teknik Accidental Sampling yaitu metode pengambilan sampel dengan memilih sampel dari orang atau unit yang paling mudah dijumpai.

Teknik pengumpulan data dalam penelitian ini diperoleh melalui cara dan tahapan sebagai berikut:

a. Observasi, yaitu penulis melakukan pengamatan langsung di lapangan pada para nasabah di Pegadaian Syariah cabang HR. Soebrantas untuk mendapatkan gambaran secara nyata baik terhadap subjek maupun objek penelitian.

b. Wawancara, yaitu teknik pengumpulan data dengan teknik tanya jawab langsung dengan responden untuk memperoleh informasi sesuai dengan data yang diperlukan.

c. Angket, yaitu penulis membuat pertanyaan berupa daftar pertanyaan sekitar penelitian ini yang kemudian disebarkan untuk diisi oleh para responden untuk memperkuat hasil penelitian.

d. Studi pustaka, yaitu dengan melihat dan menganalisis dari buku-buku yang berkaitan dengan penelitian ini.

Dalam penelitian ini penulis menggunakan metode deskriptif kualitatif yaitu dengan menggambarkan permasalahan yang diteliti secara tepat sesuai dengan data yang diperoleh, kemudian di analisa secara kualitatif.

Setelah data terkumpul maka penulis mengolah data tersebut dengan menggunakan metode sebagai berikut:

a. Metode deduktif, adalah suatu uraian penulisan yang diawali dengan menggunakan kaidah-kaidah umum kemudian dianalisis dan diambil kesimpulan secara khusus.

b. Metode induktif, adalah suatu uraian penulisan yang diawali dengan menggunakan kaidah-kaidah khusus kemudian dianalisis dan diambil kesimpulan secara umum.

c. Metode deskriptif, adalah suatu uraian penulisan yang menggambarkan secara utuh dan apa adanya tanpa mengurangi atau menambah sedikit pun.

\section{Al-Muqayyad}

Vol. 4 No. 1 (2021) 
Sri Widiastuti, \& Nurse Fatimah MZ

\section{HASIL DAN PEMBAHASAN}

\section{Aplikasi Akad Rahn}

Sejak didirikannya pegadaian, hingga saat ini pegadaian tetap berbakti untuk lapisan masyarakat yang paling bawah. Kiprahnya yang bertumpu pada sumbangan dan kesetiaan pelanggan, tekun mengumpulkan receh demi recehan. Pola hidupnya yang sederhana menyebabkan pegadaian tidak pernah menyusahkan pemiliknya. Kebajikan dan nilai moral itulah yang mendorong untuk selalu menekuni pelanggannya.

Meminjam uang di pegadaian syariah prosedurnya relatif mudah dan cepat. Adapun syarat yang dipenuhi oleh masyarakat adalah sebagai berikut:

1. Membawa kartu identitas (KTP/SIM/Paspor) yang masih berlaku beserta fotokopinya.

2. Membawa barang yang akan dijadikan agunan seperti perhiasan emas, logam mulia/batangan, kendaraan bermotor maupun elektronik.

3. Membuat surat kuasa di atas materai dari pemilik barang, untuk bukan milik rahin, harus dilampiri fotokopi KTP pemilik barang dan menunjukkan aslinya.

4. Mengisi serta menandatangani formulir permintaan Rahn

5. Menandatangani surat bukti rahn (SBR) dan ijarah apabila setuju dengan pinjaman yang diberikan.

6. Membayar biaya administrasi.

Penentuan uang pinjaman besarnya marhun bih dihitung berdasarkan nilai taksiran. Nilai taksiran ditetapkan dari harga pasar barang, misal:

Apabila penaksir menentukan angka hasil hitungan Rp. 10.000.000 kemudian dalam surat edaran ditetapkan bahwa besarnya marhun bih adalah $90 \%$ dari nilai taksiran, maka besarnya nilai marhun bih $=90 \%$ x Rp. 10.000.000 = Rp. 9.000.000. Adapun biaya administrasi pada pegafaian syariah adalah sebagai berikut:

Tabel 1

Penggolongan pinjaman dan biaya administrasi

\begin{tabular}{cccc}
\hline $\begin{array}{c}\text { Golongan } \\
\text { Marhun bih }\end{array}$ & \multicolumn{2}{c}{ Platform Marhun Bih (Rp) } & $\begin{array}{c}\text { Biaya } \\
\text { Administrasi }\end{array}$ \\
\hline A & \multicolumn{2}{c}{ s.d 500.000} & 5.000 \\
B & 501.000 & s.d 1.000 .000 & 8.000 \\
C & 1.005 .000 s.d 5.000 .000 & 16.000 \\
D & 5.010 .000 & s.d 10.000 .000 & 25.000 \\
E & 10.050 .000 & s.d 20.000 .000 & 40.000
\end{tabular}

Al-Muqayyad

Vol. 4 No. 1 (2021) 
Persepsi Nasabah terhadap Akad Rahn pada Pegadaian Syariah

$\begin{array}{lccc}\text { F } & 20.100 .000 & \text { s.d } 50.000 .000 & 50.000 \\ \text { G } & 50.100 .000 & \text { s.d } 200.000 .000 & 60.000\end{array}$

Pada pegadaian syariah cabang Soebrantas, sistem pelunasan pinjaman dapat dilakukan setiap saat tanpa harus menunggu habisnya jangka waktu akad, dengan jangka waktu pengembalian selama 4 tahun (120 hari). Kemudian selama proses waktu pengembalian pinjaman sampai penerimaan kembali barang jaminan tidak dikenakan biaya apa pun, kecuali membayar jasa simpanan sesuai tarif.

Akad yang digunakan oleh pegadaian syariah yaitu akad rahn dan ijarah. Penjelasan secara rinci mengenai kedua akad dimaksud, tertera pada lembar belakang SBR, sehingga dengan demikian nasabah (rahin) memahami apa yang hendak dilakukan.

\section{Akad Rahn}

Akad rahn yaitu menahan harta milik peminjam sebagai jaminan atas pinjaman yang diterimanya. Pada rahn nasabah (rahin) menyepakati untuk menyimpan (marhun) kepada murtahin di kantor pegadaian syariah cabang Hr. Soebrantas sehingga nasabah (rahin) akan membayar sejumlah ongkos kepada murtahin alias biaya perawatan dan perniagaan terhadap marhun.

\section{Akad ijarah}

Akad ijarah merupakan penggunaan manfaat atau jasa pengganti kompensasi, yaitu pemilik yang menyewakan manfaat disebut muajir, sedangkan penyewa atau nasabah disebut mustajir. Sesuai yang diambil manfaatnya (tempat penitipan) disebut majur dengan kompensasi atau balas jasa yang disebut dengan ujaran atau ujrah. Karena itu, nasabah (rahin) akan memberikan biaya kepada muajjir karena telah menitipkan barangnya untuk dijaga dan dirawat oleh murtajin.

Tabel 2

Tabel perhitungan Tarif Pegadaian Syariah

\begin{tabular}{lll}
\hline No & Jenis Marhun & Perhitungan tarif \\
\hline 1 & Emas, berlian & Taksiran/Rp. $10.000 \times \mathrm{Rp} 85 \times$ jangka waktu/10 \\
2 & Elektronik & Taksiran/Rp $10.000 \times \mathrm{Rp} .90 \times$ jangka waktu/10 \\
3 & Kendaraan bermotor & Taksiran/Rp. $10.000 \times \mathrm{Rp} .95 \times$ jangka waktu/10 \\
\hline
\end{tabular}

Adapun tumus perhitungan tarif ijarah adalah $=\mathrm{N} \times \mathrm{T} \times \mathrm{W}$

Pelunasan pinjaman dapat dilakukan dengan cara sebagai berikut:

1. Nasabah datang ke pegadaian syariah dengan membawa surat akad rahn

\section{Al-Muqayyad}

Vol. 4 No. 1 (2021) 
2. Nasabah mengembalikan jumlah pinjaman dan jasa simpan sesuai dengan tarif yang telah ditetapkan.

3. Petugas penaksir mengambil barang gadaian dan menyerahkannya kepada nasabah yang bersangkutan

Apabila hingga batas waktu yang ditetapkan nasabah tidak melunasi pinjaman, maka waktu pengembalian dapat diperpanjang lagi dengan membayar administrasi dan jasa simpanan dengan jalan melalui akad baru atau barang jaminan akan dilelang sesuai ketentuan yang berlaku di Pegadaian Syariah.

Sebelum dilakukan penjualan/lelang, rahin terlebih dahulu akan diberi peringatan melalui telepon dan surat pemberitahuan selambat-lambatnya 5 hari sebelum tanggal penjualan, dengan cara mengirimkan surat ke alamat rahin, papan pengumuman di kantor cabang dan akhir di kantor kelurahan Kecamatan.

Apabila surat peringatan itu tidak dipedulikan oleh rahin, maka pihak pegadaian syariah menjual marhun tersebut. Dalam pelaksanaannya pelelangan barang jaminan akan menggunakan sistem penjualan, namun dalam pengarsipannya tetap merupakan pelelangan. Hal ini diterapkan karena pegadaian syariah ingin menegakkan syariat Islam secara keseluruhan, namun di sisi lain pegadaian syariah harus mengikuti peraturan yang ditetapkan oleh pegadaian konvensional, di mana pegadaian syariah juga harus menyerahkan biaya lelang dan pajak lelang.

Adapun penjualan marhun yang dilakukan oleh pegadaian syariah cabang $\mathrm{Hr}$. Soebrantas Panam Pekanbaru dengan cara apabila yang ingin dijual berupa emas, dan barang berharga lainnya maka akan dijual ke toko langganan yang telah dipercaya oleh pihak pegadaian syariah, sedangkan apabila barang elektronik dan kendaraan bermotor akan ditawarkan kepada orang-orang yang ingin membeli barang tersebut, sesuai dengan harga pasaran pada saat penjualan barang jaminan tersebut. Pihak pegadaian akan menawarkan harga kepada pembeli di atas pinjaman rahin dengan tujuan agar rahin tidak merasa dirugikan. Setelah dilakukan penjualan marhun, maka pihak pegadaian syariah menghubungi rahin kembali untuk mengkonfirmasi tentang hasil penjualan marhun tersebut. Apabila hasil penjualan marhun lebih kecil dari jumlah marhun bih maka rahin diwajibkan menutupi kekurangan tersebut, tetapi apabila hasil penjualan marhun lebih 
Persepsi Nasabah terhadap Akad Rahn pada Pegadaian Syariah

besar dari jumlah marhun bih maka akan dikembalikan kepada rahin setelah dipotong pinjaman, biaya ijarah, serta biaya lelang.

\section{Persepsi Nasabah Terhadap Aplikasi Akan Rahn}

Adapun persepsi nasabah mengenai aplikasi akad rahn pada pegadaian syariah HR. Soebrantas sebagai berikut:

Tabel 3

Menjelaskan tentang pendapat nasabah mengenai prosedur/ tata cara menjadi nasabah di pegadaian syariah

\begin{tabular}{clll}
\hline No & Alternatif Jawaban & Frekuensi & Persentase \\
\hline 1 & Sangat mudah & 10 & $20 \%$ \\
2 & Mudah & 39 & $78 \%$ \\
3 & Sangat sulit & 0 & $0 \%$ \\
4 & sulit & 1 & $2 \%$ \\
& Total & 50 & $100 \%$ \\
\hline
\end{tabular}

Tabel di atas menjelaskan bahwa 10 responden menyatakan mengenai prosedur/tata cara menjadi nasabah di pegadaian syariah sangat mudah, 39 respons menyatakan mudah, serta 1 responden menyatakan sulit.

Sehingga dapat disimpulkan bahwa mayoritas responden yaitu sebanyak 39 orang menyatakan mudah mengenai prosedur/tata cara menjadi nasabah di pegadaian syariah cabang HR. Soebrantas.

Tabel 4

Menjelaskan mengapa nasabah memilih mengajukan permohonan rahn (gadai syariah) ke pegadaian syariah cabang HR. Soebrantas

\begin{tabular}{clccc}
\hline No & \multicolumn{1}{c}{ Alternatif Jawaban } & Frekuensi & Presentasi \\
\hline 1 & Karena tidak ada dikenakan bunga & 10 & $20 \%$ \\
2 & $\begin{array}{l}\text { Ingin mengetahui mana yang lebih mudah } \\
\text { prosedurnya antara pegadaian syariah dengan }\end{array}$ & 6 & $12 \%$ \\
& $\begin{array}{l}\text { konvensional } \\
3\end{array}$ & & \\
4 & Karena butuh dana cepat & 31 & $62 \%$ \\
& Ingin mencoba saja & 3 & $6 \%$ \\
\hline
\end{tabular}

Tabel di atas menjelaskan bahwa 10 responden (20\%) menjawab memilih mengajukan permohonan pinjaman ke pegadaian syariah cabang HR. Soebrantas karena tidak ada dikenakan bunga, 6 responden (12\%) menjawab karena ingin mengetahui mana Al-Muqayyad

Vol. 4 No. 1 (2021) 
Sri Widiastuti, \& Nurse Fatimah MZ

yang lebih mudah prosedurnya antara Pegadaian Syariah dengan Pegadaian Konvensional, 31 responden (62\%) menjawab karena butuh dana cepat, serta 3 responden menjawab karena ingin mencoba saja.

Sehingga dapat disimpulkan bahwa faktor utama responden melalukan transaksi rahn (gadai syariah) di Pegadaian Syariah cabang HR. Soebrantas adalah karena nasabah sangat membutuhkan dana cepat, guna memenuhi kebutuhannya.

Tabel 5

Menjelaskan pendapat nasabah mengenai keuangan barang jaminan/agunan yang merdeka gadaikan di pegadaian syariah cabang HR. Soebrantas

\begin{tabular}{llcc}
\hline No & \multicolumn{1}{c}{ Alternatif jawaban } & frekuensi & Perentase \\
\hline 1 & $\begin{array}{l}\text { Sebagai pedoman bagi pihak pegadaian syariah } \\
\text { dalam memberikan jumlah pinjaman }\end{array}$ & 32 & $64 \%$ \\
2 & $\begin{array}{l}\text { Sebagai jaminan jika terjadi pembayaran } \\
\text { bermasalah (pembayaran pinjaman macet) }\end{array}$ & 18 & $36 \%$ \\
& Total & 50 & $100 \%$ \\
\hline
\end{tabular}

Tabel di atas menjelaskan bahwa 32 responden (64\%) berpendapat mengenai kegunaan barang jaminan/agunan yang mereka gadaikan di pegadaian syariah yaitu pedoman bagi pihak pegadaian dalam memberikan jumlah pinjaman dan 18 orang responden menjawab sebagai jaminan jika terjadi pembayaran bermasalah.

Sehingga dapat disimpulkan bahwa mayoritas responden yaitu sebanyak 32 orang beranggapan bahwa barang jaminan yang mereka gadaikan digunakan sebagai pedoman bagi pihak pegadaian syariah dalam memberikan jumlah pinjaman yang mereka butuh kan, dari wawancara penulis dengan salah satu nasabah, mereka mengatakan uang yang saya butuh kan terbilang sekian tetapi barang yang saya gadaikan itu ternyata hanya sekian rupiah pinjaman yang bisa saya dapatkan dari barang jaminan tersebut.

Tabel 6

Menjelaskan apakah dalam akad rahn dijelaskan tentang risiko jika terjadi pembayaran bermasalah

\begin{tabular}{clcc}
\hline No & Alternatif Jawaban & frekuensi & Persentase \\
\hline 1 & Dijelaskan & 50 & $100 \%$ \\
2 & Tidak dijelaskan & 0 & $0 \%$ \\
& Total & 50 & $100 \%$ \\
\hline
\end{tabular}


Persepsi Nasabah terhadap Akad Rahn pada Pegadaian Syariah

Tabel di atas menjelaskan bahwa 50 responden menjawab ada penjelasan mengenai risiko pembayaran bermalah. Sehingga dapat disimpulkan bahwa sebelum terjadinya akad rahn pihak pegadaian syariah terlebih dahulu menjelaskan kepada nasabah mengenai pembayaran bermasalah.

Tabel 7

\begin{tabular}{clcc}
\hline No & Alternatif jawaban & frekuensi & Persentase \\
\hline 1 & Iya & 12 & $24 \%$ \\
2 & Tidak & 22 & $44 \%$ \\
3 & Tidak tahu & 2 & $4 \%$ \\
4 & Ragu-ragu & 14 & $28 \%$ \\
& Total & 50 & $100 \%$ \\
\hline
\end{tabular}

Tabel di atas menjelaskan bahwa 12 responden menjawab produk gadai yang ada di perusahaan pegadaian syariah dan pegadaian konvensional adalah sama, 22 responden menjawab tidak sama, 2 responden menjawab tidak tahu 14 responden menjawab raguragu. Sehingga dapat disimpulkan bahwa produk gadai yang ada di pegadaian syariah dan konvensional tidak sama, tetapi masih ada nasabah yang menyatakan bahwa produk pegadaian syariah dan konvensional sama.

Alasan mereka menganggap gadai konvensional sama adalah sama-sama dikenakan bunga/kelebihan pembayaran pada saat pengembalian pinjaman. Jadi jelaskah bahwa anggapan nasabah yang mengatakan gadai syariah dan gadai konvensional sama disebabkan karena tidak pahamnya nasabah tersebut terhadap sistem akad rahn yang diterapkan di pegadaian syariah.

\section{Tabel 8}

Menjelaskan apakah menurut nasabah biaya ijarah itu sama dengan bunga

\begin{tabular}{clcc}
\hline No & Alternatif jawaban & frekuensi & persentase \\
\hline 1 & Iya, sama & 16 & $32 \%$ \\
2 & Tidak sama & 25 & $50 \%$ \\
3 & Ragu-ragu & 9 & $18 \%$ \\
& Total & $50 \%$ & $100 \%$ \\
\hline
\end{tabular}

Tabel di atas menjelaskan bahwa 16 responden menyatakan bahwa biaya ijarah sama dengan bunga, 25 responden menyatakan tidak sama dengan bunga, serta 0 responden menyatakan ragu-ragu apakah biaya ijarah sama dengan bunga atau tidak. Sehingga dapat disimpulkan bahwa mayoritas nasabah menganggap bahwa biaya ijarah tidak sama dengan bunga.

\section{Al-Muqayyad}

Vol. 4 No. 1 (2021) 
Sri Widiastuti, \& Nurse Fatimah MZ

Tabel 9

Menjelaskan pendapat nasabah mengenai aplikasi akad rahn yang diterapkan oleh pegadaian syariah apakah sudah sesuai dengan ekonomi Islam

\begin{tabular}{clll}
\hline No & Alternatif Jawaban & Frekuensi & Persentase \\
\hline 1 & Sesuai & 26 & $52 \%$ \\
2 & Belum sesuai & 2 & $4 \%$ \\
3 & Ragu-ragu & 17 & $32 \%$ \\
4 & Tidak Tahu & 5 & $10 \%$ \\
& Total & $50 \%$ & $100 \%$ \\
\hline
\end{tabular}

Tabel di atas menjelaskan bahwa 26 responden menyatakan aplikasi akad rahn yang diterapkan oleh pegadaian syariah cabang HR. Soebrantas Pekanbaru sudah sesuai dengan ekonomi Islam, 2 responden menyatakan aplikasi akad rahn belum sesuai dengan ekonomi Islam, 17 responden menyatakan ragu-ragu apakah aplikasi akad rahn yang diterapkan sudah sesuai atau belum, serta 5 responden menyatakan tidak tahu apakah aplikasi akad rahn yang diterapkan oleh pegadaian syariah cabang Hr. Soebrantas sudah sesuai dengan ekonomi Islam apa belum.

Sehingga dapat disimpulkan bahwa mayoritas nasabah menyatakan aplikasi akad rahn yang diterapkan oleh pegadaian syariah cabang HR. Soebrantas sudah sesuai dengan ekonomi Islam, tetapi masih ada nasabah yang menyatakan belum sesuai dan bahkan tidak mengetahui ekonomi Islam yang diterapkan oleh pegadaian syariah apakah sudah diterapkan atau belum.

\section{SIMPULAN}

Implementasi menggunakan akad rahn dan ijarah. Apabila hingga batas waktu yang ditetapkan rahin tidak mampu melunasi pinjaman, maka masa pelunasan dapat diperpanjang dengan membayar administrasi dan jasa simpan melalui akad baru atau marhun akan dilelang. Apabila hasil penjualan lebih kecil dari jumlah marhun bih, maka rahin berkewajiban membayar kekurangannya, namun apabila hasil penjualan melebihi dari jumlah marhun bih setelah dikurangi biaya ijarah dan biaya pelelangan, maka sisanya dikembalikan kepada rahin.

Meski sebagian nasabah tidak benar-benar memahami apa itu akad rahn, tetapi mereka beranggapan bahwa produk gadai yang ada di Pegadaian Syariah dan produk gadai yang ada di Pegadaian konvensional tidaklah sama. Walaupun masih ada sebagian 
Persepsi Nasabah terhadap Akad Rahn pada Pegadaian Syariah

nasabah yang beranggapan bahwa produk gadai yang ada di Pegadaian Syariah dan produk gadai yang ada di Pegadaian konvensional adalah sama.

Aplikasi akad rahn pada Pegadaian Syariah cabang HR. Soebrantas Pekanbaru telah sesuai dengan ekonomi Islam, karena dalam penerapannya tidak ada hal-hal yang melanggar syariat Islam, dan tidak ada ditemukan dalil Al-Quran dan Hadits Nabi SAW yang melarang untuk melakukan pegadaian.

\section{REFERENSI}

Abdullah, A. A. (2006). Syarah Bulughulmaram, Jakarta: Pustaka Azzam.

Ali, Z. (2008). Hukum Gadai Syariah. Jakarta: Sinar Grafika

Andri, S. (2010). Bank dan Lembaga Keuangan Syariah. Jakarta: Kencana.

Anshori, A. G. (2006). Gadai Syariah di Indonesia. Yogyakarta.

Antonio, M. S. (2001). Bank Syariah dari Teori ke Praktik. Jakarta: Gema Insani.

Buchari, A., \& Doni, J. P. (2009). Manajemen Bisnis Syariah. Bandung: CV. Alfabeta.

Dewan Syariah Nasional Majelis Ulama Indonesia. (2002). Himpunan Fatwa Dewan Syariah Nasional. Jakarta: PT. Intermasa.

Hadi, M. S. (2003). Pegadaian Syariah. Jakarta: Salemba Diniyah.

Harun, N. (2007). Fiqh Muamalah. Jakarta: Gaya Media Pratama.

Muhammad. (2000). Lembaga-lembaga Keuangan Umat Kontemporer. Yogyakarta: UII Press.

Muhammad. (2008). Metodologi Penelitian Ekonomi Islam. Jakarta: Rajagrafindo Persada.

Muslehuddin, M. (2004). Sistem Perbankan Dalam Islam. Jakarta: PT. Asdi Mahasatya.

Nurhayati, S. (2008). Akuntansi Syariah di Indonesia. Jakarta: Salemba Empat.

Ridwan, M. ((2004). Manajemen BMT. Yogyakarta: UII Press.

Rifqi, M. (2008). Akuntansi Keuangan Syariah,Konsep dan Implementasi PSAK Syariah. Yogyakarta: P3EI Press.

Soemitra, A. (2010). Bank dan Lembaga Keuangan Syariah. Jakarta: Kencana.

Sutedi, A. (2011). Hukum Gadai Syariah. Bandung: Alfabeta.

Veithzal, R., Andria, P. V., \& Ferry, N. I. (2007). Bank and Financial Institution Management. Jakarta: PT Rajagrafindo Persada. 